\title{
School Performance and Symptoms of Depression, Anxiety, and Stress in Adolescents
}

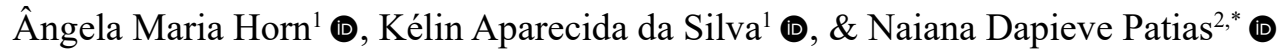 \\ ${ }^{1}$ IMED, Passo Fundo, RS, Brasil \\ ${ }^{2}$ Universidade Federal de Santa Maria, Santa Maria, RS, Brasil
}

\begin{abstract}
The objective of this study was to verify the correlation between school performance and symptoms of depression, anxiety, and stress in 432 public school students aged from 15 to 18 years. The instruments used were a sociodemographic datasheet, Escala de Depressão, Ansiedade e Estresse (EDAE-A), and the grades in the courses/areas of interest of three school trimesters. Descriptive analyses, as well as the Mann-Whitney U test and Spearman's correlation test, were conducted. A weak and negative correlation was found between school performance and anxiety and depression symptoms, with the adolescents from full-time schools presenting better performance and fewer symptoms of depression and anxiety than those in regular schools. Younger adolescents presented more stress symptoms, while female adolescents have more depression and anxiety symptoms.
\end{abstract}

KEYWORDS: school performance, depression, anxiety, stress, adolescence

\section{Desempenho Escolar e Sintomas de Depressão, Ansiedade e Estresse em Adolescentes}

\begin{abstract}
RESUMO - Objetivou-se verificar a correlação entre desempenho escolar, sintomas de depressão, ansiedade e estresse em 432 estudantes de escolas públicas, de idades entre 15 e 18 anos. Os instrumentos foram uma ficha de dados sociodemográfica, a Escala de Depressão, Ansiedade e Estresse (EDAE-A) e as notas nas disciplinas/áreas dos três trimestres letivos. Análises descritivas, bem como teste $U$ de Mann-Whitney e correlação de Spearman foram realizadas. Verificou-se correção fraca e negativa entre desempenho escolar e sintomas de ansiedade e depressão, tendo os adolescentes de escolas de turno integral, maior desempenho e menores sintomas de depressão e ansiedade que os da escola regular. Adolescentes mais novos apresentaram maiores sintomas de estresse e adolescentes do sexo feminino possuem maiores sintomas de depressão e ansiedade.
\end{abstract}

PALAVRAS-CHAVE: desempenho escolar, depressão, ansiedade, estresse, adolescência

The official indices related to the school performance of Brazilian students cause concern. According to data from the Program for International Student Assessment (PISA), Brazil presented performance below expectations compared to students from all over the world (Organization for Economic Cooperation and Development, 2018). Regarding the school performance construct, it has been studied nationally and internationally, having been conceptualized and measured in different ways (Mahendra \& Marin, 2015; Menezes-Filho, 2007). This assessment generally takes place through school grades (Wang et al., 2012), standardized tests
(Sy et al. 2013) or is analyzed through the low proficiency in subjects, the age-grade distortion, number of failings, low attendance, or school evasion, among others (Franceschini et al., 2016). Although there is no consensus regarding the concept and its assessment form, it is known that it is an important factor that influences the student's schooling and their later development (Menezes-Filho, 2007).

Many factors influence school performance. For example, age has been an important aspect, and, under the perspective of failing, school performance tends to decrease with age since failures tend to increase over the years

*E-mail: naiana.patias@ufsm.br

- Submetido: 03/06/2019; Aceito: 25/09/2020. 
(Franceschini et al., 2016). For example, women aged from 17 to 19 years old have over five times the chance of failing than those aged 15. For men, the chance may be 11 times greater at 18 years old than at 15 (Franceschini et al., 2016).

In adolescence, specifically, studies that investigate the factors that influence school performance in this stage of life report that there are contextual aspects related to the school and family institutions, which are important aspects to be considered (Bonamino et al., 2010; Cavalcante \& Santos Júnior, 2013; Landstedt \& Gadin, 2012; Pozzobon et al., 2018) since the context in which the adolescent lives has an impact on his development.

Regarding the contextual aspects, it stands out that the physical environment of the school and the qualification of the teacher are also important variables that must be considered. Concerning the family, some particular characteristics such as the education level of the parents, their presence and/or absence, the form of interaction among the members, and how the parents perceive the school interfere with the school performance of the adolescents (Rotta et al., 2016). In turn, regarding the individual factors, the developmental aspects of the adolescence stage itself merit attention (Martinelli \& Genari, 2009; Osti \& Brenelli, 2012) and are also important factors.

Adolescence refers to a period of significant vulnerability for some depression and anxiety symptoms due to the countless biological, psychological, and social changes of the development stage itself (Thapar et al., 2012; Van Oort et al., 2009). Besides the development stage, being female increases the chances of witnessing symptoms of anxiety, depression, and stress (Germain \& Marcotte, 2016; Soares $\&$ Martins, 2010). This difference may remain stable over the entire adolescence (Van Oort et al., 2009).

Experiencing mental disorder symptoms impacts the daily life of any adolescent because it ends up interfering with the way they perceive the situations and behave, causing social and educational damage (Fletcher, 2010; Thapar et al., 2012). Regarding the educational damages, school performance stands out. For example, a study carried out in Portugal with 1,816 high school adolescents aged from 14 to 22 years old found that the adolescents who presented depressive disorder symptoms are those with the lowest school performance (Benevides et al., 2015).

There are studies highlighting the relation between school performance and symptoms of depression (Benevides et al., 2015) and anxiety (San Martín et al., 2016). For example, a national study conducted with 210 high school adolescents aged from 14 to 18 years old indicated that the depressive symptomatology interfered negatively with school performance (Monteiro et al., 2007). Another Brazilian study, also held with high school students (from 15 to 24 years old), pointed out that depression includes cognitive symptoms such as attention deficit, which, in turn, may interfere with the performance of the adolescents (Baptista et al., 2006).
In turn, anxiety seems to be another important aspect that contributes to poorer school performance. In a study conducted in Chile with 1,314 adolescents from 13 to 17 years old, it was found that there is a relationship between school success/failure and anxiety and that adolescents who had less school success presented anxiety levels significantly higher than those with less failure (San Martín et al., 2016). One may hypothesize that anxiety hampers adolescents from managing to concentrate on school tasks and, thus, end up performing poorly on school evaluations. On the other hand, one may also explain anxiety as a result of not achieving "expected" levels in evaluations. Indeed, a study carried out in Brazil with high school students found that adolescents who presented high anxiety scores had more difficulty learning and were more prone to evasion. Such adolescents were also more prone to self-demand for performance, feelings of incapacity, and psychophysiological reactions that impaired retaining content (Gonzaga et al., 2016).

Besides depression and anxiety symptoms, stress symptoms also play an important role in school performance (Marques et al., 2015). Stress in adolescence may be considered a factor responsible for the development of psychological problems (Marques et al., 2015). Academic activities are among the most relevant factors for increasing stress indicators in adolescents (Marques et al., 2015).

Regarding the variables that influence symptoms of depression, anxiety, and stress, the gender and age of the adolescents seem to be a relevant aspect. About gender, girls present higher scores for symptoms than boys (Germain \& Marcotte, 2016; Jaureguizar et al., 2015; Liu \& Lu, 2012). About the age, there is no consensus, yet some studies indicate that, at the beginning of adolescence, there is a higher prevalence of symptoms (Germain \& Marcotte, 2016; Soares \& Martins, 2010). Overall, emotional and behavioral indicators identified contribute to explaining the school performance of adolescents, which indicates that such factors must be considered within the scope of education and health, with emphasis on the concern in identifying the specific effects of the emotional and behavioral problems over school performance (Borba \& Marin, 2017).

The studies aimed at understanding the factors associated with school performance are mostly directed towards elementary school (Franceschini et al., 2016). Only recently did high school begin to draw the attention of governments, research, and the subjects involved, with a panorama of secondary priority in educational public policies up to the beginning of the 2000s (Krawczyk \& Silva, 2017). Moreover, the adolescent population has reached little attention regarding mental health (Ministério da Saúde, 2010; Macedo et al., 2018; Taño \& Matsukura, 2019).

Still, Brazilian studies turn to the evaluation of symptoms of depression, anxiety, and stress independently (Patias et al., 2016), besides using different ways of assessing school performance. In view of the exposed, the need for studies that explore the issues related to the school performance of 
adolescents, specifically in high school, as a consequence of the complexity of the factors involved is evident.

Hence, the present study aimed to verify the correlation between school performance and symptoms of depression, anxiety, and stress in high school adolescents. As specific objectives, we aimed to analyze if there were statistically significant differences in the constructs investigated by gender, age range, and school type (regular and full time).

\section{METHOD}

This is a quantitative and cross-sectional study of descriptive and correlational nature.

\section{Participants}

Participating in the study were 432 adolescents, 247 (57\%) female, aged from 15 to 18 years $(M=16.32 ; S D=0.86)$ from a city in the north of the state of Rio Grande do Sul, contacted by convenience. The number of participants was determined by a sample calculation considering the number of students enrolled in High School in the city, with a $5 \%$ error margin.

The adolescents were students from the first to the third year of High School, with 210 being first-year students (47 $\%$ ), 127 being second-year students (29\%), and 95 being third-year students (22\%), with 234 (54\%) coming from full-time military schools and 197 from regular schools (46 $\%)$. Regarding failures, 81 students (19\%) self-reported they had failed at least once before. Concerning the family characteristics, 246 of the adolescents lived with the biological parents or biological parents and siblings, being from nuclear families $(57 \%), 110$ lived with their uncles, aunts, grandmothers, or foster parents ( $26 \%$ ), 40 lived only with their mothers, in female single-parent families ( $9 \%), 32$ adolescents lived with their step-parents and parents, being from families considered reconstituted (7\%). Lastly, only 4 adolescents lived only with their fathers (1\%).

\section{Instruments}

The data collection instruments were the following:

\section{Sociodemographic Questionnaire}

Designed for this study, it has questions regarding age, gender, education level, and family setting, among others.

\section{School Performance Assessment}

School performance was evaluated from the overall grade (score) by area of knowledge corresponding to the first, second, and third trimesters of the school year of 2017.

\section{Escala de Depressão, Ansiedade e Estresse para Adolescentes (EDAE-A) (Patias et al., 2016)}

This scale was adapted and validated to be applied to Brazilian adolescents from the DASS-21 instrument, translated and validated in Brazil for adults (Machado, 2013).
It is composed of 21 statements answered through Likert scales from 0 (Did not happen to me this week) to 3 (Happened to me most of the time this week). The confirmatory analysis results indicated a good internal consistency for the overall scale and subscales $(\alpha=0.83$ to 0.90$)$.

\section{Procedures}

Upon approval by the Research Ethics Committee of Faculdade Meridional/IMED, the lead researcher initiated contact with some schools in the city. After the acceptance by the institutions, there were invitations made to the high school students of the schools, explaining the objective of the research and delivering the Free and Informed Consent Form (FICF) for them to send to their parents and/ or persons responsible, as well as the Free and Informed Assent Form (FIAF) for the adolescents to sign. A new classroom visit was made on a date previously scheduled with the school, and the data collection was initiated with the adolescents who had the signed FICF and FIAF. The collection took place collectively, in the classroom, in pen and paper format, with an approximate duration of $60 \mathrm{~min}$ for each class. Afterward, at both schools, the grades from the three school trimesters were made available (2017). All ethical aspects were followed according to the Regulating Guidelines and Standards for Research Involving Human Beings (Resolutions No. 466/2012 and 510/2016).

\section{Data Analysis}

Firstly, the means of the school grades were collected by trimester. At school A, full time, the grades were by subject. In turn, at school B, the final grades were by area; however, over the trimesters, the grades were by subject, which allowed them to be obtained. After, we chose to transform the grades from both schools into four large areas according to school B. The grades of the three trimesters of each subject were summed. The overall grade for each subject was summed to derive the area, namely Nature Sciences (Biology, Physics, and Chemistry), Human Sciences (Philosophy, Geography, History, and Sociology), Languages (Art, Physical Education, Literature, Modern Foreign Language - English, and Portuguese), and Mathematics. The religious education grades were not part of the final grade because, in school B, some students chose not to attend the subject. Lastly, the overall mean was obtained. The depression, anxiety, and stress scores were summed 
according to the items of the instruments and, then the sum of the total mean was carried out.

Descriptive analyses (means and standard deviations) were performed with the aim of verifying the mean, standard deviation, minimums, and maximums of each construct. Mann-Whitney $U$ tests were performed to compare the means of the school performance scores and depression, anxiety, and stress symptoms by gender, age range, and school type (full time and regular). With the objective of verifying if there was a correlation between school performance and depression, anxiety, and stress symptoms, Spearman's correlation test was performed. Non-parametric analyses were carried out due to the non-normality of the distribution of the variables investigated.

\section{RESULTS}

The correlation between the total school performance and the depression, anxiety, and stress symptoms was verified through Spearman's correlation coefficient. The analysis indicated a significant, negative, and weak correlation between school performance and depression symptoms (rho $=-0.11 ; p=0.03$ ) and between school performance and anxiety symptoms (rho $=-0.18 ; p<$ 0.001).

Mann-Whitney $U$ tests were carried out with the goal of verifying differences in school performance and symptoms by school type (full time and regular), gender, and age range. Table 1 indicates a statistically significant difference in school

Table 1

Differences in School Performance and Depression, Anxiety, and Stress Symptoms by School Type (Full Time or Regular), Gender, and Age Range

\begin{tabular}{|c|c|c|c|c|c|c|}
\hline & & & $M$ & $S D$ & $U$ & $p$ \\
\hline \multirow{6}{*}{$\begin{array}{l}\text { Total school } \\
\text { performance }\end{array}$} & \multirow{2}{*}{ School } & Full time $(n=235)$ & 84.67 & 7.50 & \multirow{2}{*}{3410.00} & \multirow{2}{*}{$<0.001$} \\
\hline & & Regular ( $n=197)$ & 67.15 & 10.34 & & \\
\hline & \multirow{2}{*}{ Gender } & Boys $(n=185)$ & 76.10 & 12.75 & \multirow{2}{*}{22291.50} & \multirow{2}{*}{0.66} \\
\hline & & Girls $(n=247)$ & 77.05 & 12.23 & & \\
\hline & \multirow{2}{*}{ Age range } & Younger $(n=260)$ & 78.25 & 12.03 & \multirow{2}{*}{18560.00} & \multirow{2}{*}{0.003} \\
\hline & & Older $(n=172)$ & 74.22 & 12.71 & & \\
\hline \multirow{6}{*}{ Depression } & \multirow{2}{*}{ School } & Full time $(n=235)$ & 5.70 & 4.62 & \multirow{2}{*}{21046.50} & \multirow{2}{*}{0.04} \\
\hline & & Regular ( $n=197)$ & 7.12 & 5.80 & & \\
\hline & \multirow{2}{*}{ Gender } & Boys $(n=185)$ & 4.41 & 4.24 & \multirow{2}{*}{13012.50} & \multirow{2}{*}{$<0.001$} \\
\hline & & Girls $(n=247)$ & 7.80 & 5.44 & & \\
\hline & \multirow{2}{*}{ Age range } & Younger $(n=260)$ & 6.58 & 5.42 & \multirow{2}{*}{208220.00} & \multirow{2}{*}{0.42} \\
\hline & & Older $(n=172)$ & 6.01 & 4.94 & & \\
\hline \multirow{6}{*}{ Anxiety } & \multirow{2}{*}{ School } & Full time $(n=235)$ & 3.59 & 3.96 & \multirow{2}{*}{21428.50} & \multirow{2}{*}{0.001} \\
\hline & & Regular ( $n=197)$ & 5.13 & 4.67 & & \\
\hline & \multirow{2}{*}{ Gender } & Boys $(n=185)$ & 2.90 & 5.01 & \multirow{2}{*}{12959.00} & \multirow{2}{*}{$<0.001$} \\
\hline & & Girls $(n=247)$ & 5.33 & 2.96 & & \\
\hline & \multirow{2}{*}{ Age range } & Younger $(n=235)$ & 4.62 & 4.86 & \multirow{2}{*}{23142.50} & \multirow{2}{*}{0.18} \\
\hline & & Older $(n=172)$ & 3.80 & 3.88 & & \\
\hline & $\mathrm{S}, \mathrm{h}$ & Full time $(n=235)$ & 7.65 & 4.57 & $5060-50$ & > \\
\hline & School & Regular ( $n=197)$ & 8.02 & 5.73 & 20059.500 & 0.99 \\
\hline Stroct & Gondor & Boys $(n=185)$ & 5.65 & 4.25 & 1645000 & 046 \\
\hline Stress & Gender & Girls $(n=247)$ & 9.44 & 5.14 & 10459.00 & 0.40 \\
\hline & 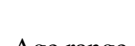 & Younger $(n=235)$ & 8.02 & 5.32 & 1000200 & - 0001 \\
\hline & Age range & Older $(n=172)$ & 7.51 & 4.83 & 18893.00 & $<0.001$ \\
\hline & Solor & Full time $(n=235)$ & 16.94 & 11.38 & 2122050 & 007 \\
\hline & Schoor & Regular ( $n=197)$ & 20.26 & 14.64 & 21500.50 & 0.01 \\
\hline $\mathrm{FDAF} A$ & Condo & Girls $(n=247)$ & 22.57 & 13.86 & 1270100 & -0001 \\
\hline LDAL- & Uentider & Boys $(n=185)$ & 12.96 & 9.46 & $13 / 01.00$ & $<0.001$ \\
\hline & A or ranor & Younger $(n=235)$ & 19.22 & 13.76 & م & 030 \\
\hline & Age range & Older $(n=172)$ & 17.31 & 11.87 & 20438.00 & 0.30 \\
\hline
\end{tabular}

Note: Table elaborated by the authors (2018). 
performance by school type, with adolescents from the fulltime school presenting better performance compared to those in the regular school. Younger adolescents have better school performance than older ones. There were no statistically significant differences in school performance by gender.

Regarding depression, anxiety, and stress symptoms, the adolescents from the regular school presented higher scores for anxiety and depression symptoms than those in the full-time school. Per gender, compared to the boys, the girls presented higher scores for depression and anxiety symptoms, with the difference being statistically significant. Per age range, only stress symptoms presented differences between younger and older adolescents, with the first showing the highest scores.

\section{DISCUSSION}

Through Spearman's correlation coefficient, this study verified that there was a negative and weak correlation between anxiety and depression symptoms and school performance. One may state that, in this sample, adolescents with more anxiety and depression symptoms have poorer school performance, and/or adolescents with greater school performance have less anxiety and depression symptoms. Studies conducted in national and international contexts corroborate this research (Baptista et al., 2006; Benevides et al., 2015; Fletcher, 2010; Germain \& Marcotte, 2016; Monteiro et al., 2007; Ortega et al., 2014).

Although the correlation is weak, other studies state that the depression and anxiety symptoms may entail damage to student's performance since they compromise the quality of the attention (Baptista et al., 2006), possibly leading to difficulties in learning and retaining new contents, besides associating to stressors related to self-demand for performance and feelings of incapacity (Gonzaga et al., 2016). On the other hand, depression may be the cause or consequence of poor school performance since, according to the circumstances, the adolescents may present themselves as depressed, with difficulties in participating and performing class tasks, showing more signs of fatigue and sadness than their classmates who do not present depression symptoms (Moreno et al., 2009).

Regarding the symptoms, when compared by gender, girls obtained higher means for anxiety and depression symptoms than boys. About the scores related to the symptoms, this study corroborates previous ones that indicate that girls present more symptoms of anxiety (Germain \& Marcotte, 2016; Patias et al., 2016; Soares \& Martins, 2010), depression (Baptista et al., 2006; Germain \& Marcotte, 2016; Jaureguizar et al., 2015; Lopes \& Rezende, 2013; Ortega et al., 2014; Patias et al., 2016; Pérez \& Urquijo, 2001; Salle et al., 2012), and stress (Patias et al., 2016).

A study carried out with 407 high-school students from the city of Maceió indicated differences between gender for anxiety symptoms, with females presenting a higher frequency of anxiety compared to males (Lopes \& Rezende, 2013). These results are similar to those from other national studies investigating the symptoms by comparing boys and girls (Manso \& Matos, 2006; Patias et al., 2016; Rodrigues \& Pelisoli, 2008). In a national study conducted to adapt and validate the Depression Anxiety and Stress Scale (DASS-21) to Brazilian adolescents, it was found that girls present higher scores for depression, anxiety, and stress symptoms than boys (Patias et al., 2016). The difference found in the symptoms may be explained by the gender roles attributed to the genders (Salle et al., 2012; Soares \& Martins, 2010). Furthermore, it is expected, for example, that girls talk more about their feelings than boys and, therefore, since the instrument is self-reported, they report their symptoms more accurately (Patias et al., 2016). One may hypothesize that, even today, girls may be educated differently from boys merely due the fact that they are girls. This may impact the expression of their feelings and influence how they respond to the surveys that involve this expression.

Differences by age range in the anxiety and depression symptoms were not found, only in the stress symptoms, which were more considerable among the younger adolescents. This aspect may be related to the development period in which the adolescents find themselves, given that, especially at the beginning of adolescence, there is a series of body changes that are fast and intense and may cause stress (Cerqueira-Santos et al., 2014; Patias et al., 2016; Senna \& Dessen, 2012). However, the results are inconclusive since not all studies indicate this path. For example, a study carried out in the state of Rio Grande do Sul investigated perceived stress in adolescents and its relationship with the family environment, sexuality, drug use, and sociodemographic variables. The results indicate that there was no difference in perceived stress between genders and among age ranges (Schermann et al., 2014). In turn, concerning the depression and anxiety symptoms, it seems that the symptoms have been presenting similarly among the adolescents regardless of age. About this, there is no agreement relative to the results of other previous studies (Patias et al., 2016).

With respect to school performance and school type (full time or regular), adolescents from the full-time school obtained better performance than those in the regular school. Concerning this, a national study verified that the full-time school presented advantages in the school life and daily life of the adolescents. The improvement to school 
performance, autonomy, and involvement of the adolescents with extracurricular activities were highlighted (Strey et al., 2017).

Although there is no consensus regarding this, it seems that the construction of a pedagogical proposal for full-time schools with appropriate study and work conditions for students and teachers may represent an increase in the quality of the educational work (Cavaliere, 2007). Extending time at school may give opportunity for transformations of school experiences, establishing new bonds, besides broadening knowledge (Borges \& Sant'Anna, 2017). However, in this study, no other aspects that may be related to the specificities of the full-time school were investigated. For example, the investigated school that had this characteristic was military. Generally, in such schools, the adolescents have good performance based on tests such as the National High School Exam (ENEM) (Benevides \& Soares, 2015; Haguette et al., 2016), besides being motivated to learn (De Souza et al., 2019). Moreover, the adolescents who are not the children of military personnel go through a selection process to enter the school. This may contribute to higher school performance and explain the difference found in this study.

Allied to the better school performance, full-time school students present lower scores for depression and anxiety symptoms than students from regular schools. This aspect may be important since it indicates that the symptoms are correlated to school performance, a result found in the current study. However, there is no consensus in literature regarding this aspect since a series of factors must be considered, given the specificity of the military school (full time) and the more considerable discipline and hierarchy (Benevides \& Soares, 2015; Haguette et al., 2016). Hence, other studies must investigate the factors associated with the school institution itself.

Another important result of this study refers to the statistically significant difference in school performance by age range. The younger adolescents presented better school performance than older ones. About this aspect, a study indicated a statistically significant difference in the school performance of adolescents regarding age, with younger ones presenting better performance (Pérez \& Urquijo, 2001). It was recently observed that the risks of failing increase with age (Franceschini et al., 2016). However, literature points to equivalent anxiety levels for both first-year (younger) and third-year (older) adolescents (Soares \& Martins, 2010). This suggests there is no consensus in literature about school performance by age range, given that there are indications that the transition from elementary school to high school may be difficult due to the more considerable demands and requirements from the students, so one may hypothesize that, for this reason, younger students would have poorer performance than the older ones. On the other hand, school failure and evasion rates are higher in highschool adolescents than those in elementary school (Silva et al., 2016).

\section{FINAL CONSIDERATIONS}

This article aimed to verify the correlation between school performance and depression, anxiety, and stress symptoms, as well as if there were statistically significant differences in the investigated constructs according to gender, age range, and school type (full time and regular). The results of the present study corroborate others but also diverge on some aspects. For example, it was found that the adolescents from the regular school presented higher scores for depression and anxiety symptoms and poorer school performance compared to those in the full-time military school. About the latter, it is important to stress that few studies have been performed in literature, which hampers the comparison of the results.

Thus, studies must investigate which variables contribute to the better school performance of the students considering aspects of risk and protection in the military environment, given that there are important characteristics of this type of school institution that must be considered when comparing with regular schools - besides the fact that they work full time.
Another relevant aspect that corroborates the current literature regards the more significant depression and anxiety symptoms in girls. This aspect may be associated with the gender roles that, on the one hand, "allow" girls to express their feelings freely but, on the other hand, prevent boys from expressing themselves openly. The education of children and adolescents still seems to preconize gender differences. Consequently, when answering the selfreporting instruments, it may be that girls express what they actually feel, while boys have a harder time expressing themselves.

The main limitation of the study refers to the way the school performance was assessed - through grade means. Although knowing that it is not ideal, there is no standardized school performance test for adolescents in Brazil, so the construction of such a test is a suggestion for future studies. Future studies may also investigate other variables associated with school performance, such as aspects of the school itself (being privately-owned, public, military, etc.) and individual and family variables involved. 


\section{REFERENCES}

Baptista, M. N., Lima, R. F., Capovilla, A. G. S., \& Melo, L. L. (2006). Sintomatologia depressiva, atenção sustentada e desempenho escolar em estudantes do Ensino Médio. Psicologia Escolar e Educacional, 10(1), 99-108. http://dx.doi. org/10.1590/S1413-85572006000100009

Benevides, A. A., \& Soares, R. B. (2015). Diferencial de desempenho das escolas militares: bons alunos ou boa escola? XXI Encontro Regional de Economia, Fortaleza, CE. https:// www.bnb.gov.br/documents/160445/960917/DIFERENCIAL DE DESEMPENHO DAS ESCOLAS MILITARES. pdf/7ae9ef81-9687-46cb-b501-766cceflcba $\overline{2}$

Benevides, J., Sousa, M., Barreto-Carvalho C., \& Nunes-Caldeira, S. (2015). Sintomatologia depressiva e (in)satisfação escolar. Revista de Estudios e Investigación en Psicología y Educación, Vol. Extr. XIII CIG-PP5(5), 13-18. https://doi.org/10.17979/ reipe.2015.0.05.109

Bonamino, A., Alves, F., Franco, C., \& Cazelli, S. (2010). Os efeitos das diferentes formas de capital no desempenho escolar: Um estudo à luz de Bourdieu e de Coleman. Revista Brasileira de Educação, 15(45), 487-499. https://doi.org/10.1590/S141324782010000300007

Borba, B. M. R., \& Marin, A. H. (2017). Contribuição dos indicadores de problemas emocionais e de comportamento para o rendimento escolar. Revista Colombiana de Psicología, 26(2), 283-294. https://www.redalyc.org/articulo. oa? $\mathrm{id}=80454275007$

Borges, E. J., \& Sant'Ana, I. M. (2017). A política de educação em tempo integral: Apropriações do ideário neoliberal. Laplage em Revista, 3(3), 178-189. https://doi.org/10.24115/S24466220201733393p.178-189

Ministério da Saúde. (2010). Diretrizes nacionais para a atenção integral à saúde de adolescentes e jovens na promoção, proteção e recuperação da saúde. Secretaria de Atenção em Saúde, Departamento de Ações Programáticas Estratégicas. http://bvsms.saude.gov.br/bvs/publicacoes/diretrizes nacionais atencao saude adolescentes jovens promocao saude.pdf

Cavalcante, C. H. L., \& Santos Júnior, P. A. (2013). Fatores que influenciam o desempenho escolar: a percepção dos estudantes do curso Técnico em Contabilidade do IFRS - Instituto Federal de Educação, Ciência e Tecnologia do Rio Grande do Sul, Campus Porto Alegre. Revista Liberato, 14(21), 29-50. https:// doi.org/10.31514/rliberato.2013v14n21.p29

Cavaliere, A. M. (2007). Tempo de escola e qualidade na educação pública. Educação \& Sociedade, 28(100), 1015-1035. https:// doi.org/10.1590/S0101-73302007000300018

Cerqueira-Santos, E., Mello Filho, O., \& Koller, S. H. (2014). Adolescentes e adolescências. In L. Habigzang, E. Schiro, \& S. H. Koller (Orgs.), Trabalhando com Adolescentes, (pp. 15-27). Artmed.

Fletcher, J. M. (2010). Adolescent depression and educational attainment: Results using sibling fixed effects. Health Economics, 19(7), 855-871. https://doi.org/10.1002/hec.1526

Franceschini, V. L. C., Miranda-Ribeiro, P., \& Gomes, M. M. F. (2016). A cor da reprovação: Fatores associados à reprovação dos alunos do Ensino Médio. Educação e Pesquisa, 42(3), 773-786. https://doi.org/10.1590/S1517-9702201609149965

Germain, F., \& Marcotte, D. (2016). Sintomas de depressão e ansiedade na transição do Ensino Secundário ao Ensino Médio: Evolução e fatores influentes. Revista Adolescência \& Saúde, 13(1), 19-28. https://cdn.publisher.gn1.link/ adolescenciaesaude.com/pdf/v13n1a03.pdf

Gonzaga, L. R. V., Silva, A. M. B. da, \& Enumo, S. R. F. (2016). Ansiedade de provas em estudantes do Ensino Médio.
Psicologia Argumento, 34(84), 76-88 https://periodicos.pucpr. br/index.php/psicologiaargumento/article/view/23309/22429

Haguette, A., Pessoa, M. K. M., \& Vidal, E. M. (2016). Dez escolas, dois padrões de qualidade. Uma pesquisa em dez escolas públicas de Ensino Médio do Estado do Ceará. Ensaio: Avaliação e Políticas Públicas em Educação, 24(92), 609-636. https://doi.org/10.1590/S0104-40362016000300005

Jaureguizar, J., Bernaras, E., Soroa, M., Sarasa, M., \& Garaigordobil, M. (2015). Sintomatología depresiva en adolescentes y variables asociadas al contexto escolar y clínico. Behavioral Psychology/Psicología Conductual, 23(2), 245-264. https://www.researchgate.net/publication/284579674 SintomatologIa_depresiva_en_adolescentes_y_variables_ asociadas al contexto escolar y clInico

Krawczyk, N., \& Silva, C. J. de O. (2017). Desigualdades educacionais no Ensino Médio brasileiro: Uma análise do perfil socioeconômico de jovens que realizaram o Exame Nacional do Ensino Médio. Sensos-e ICRE, 4(1), 12-23. http://parc.ipp. pt/index.php/sensos/article/download/2253/640

Landstedt, E., \& Gadin, K. G. (2012). Seventeen and stressed: Do gender and class matter? Health Sociology Review, 21(1), 8298. https://doi.org/10.5172/hesr.2012.21.1.82

Liu, Y., \& Lu, Z. (2012). Chinese High School students' academic stress and depressive symptoms: Gender and school climate as moderators. Stress \& Health, 28(4), 340-346. https://doi. org/10.1002/smi.2418

Lopes, A. P., \& Rezende, M. M. (2013). Ansiedade e consumo de substâncias psicoativas em adolescentes. Estudos de Psicologia (Campinas), 30(1), 49-56. https://doi.org/10.1590/S0103166X2013000100006

Macedo, J. P., Fontenele, M. G., \& Dimenstein, M. (2018). Saúde mental infantojuvenil: Desafios da regionalização da assistência no Brasil. Revista Polis e Psique, 8(1), 112-131. https://www. seer.ufrgs.br/PolisePsique/article/viewFile/80421/47211

Machado, W. L. (2013). A saúde mental positiva e sua relação com indicadores de psicopatologia, personalidade, qualidade de vida e características sociodemográficas [Tese de Doutorado não publicada]. Universidade Federal do Rio Grande do Sul.

Mahendra, F., \& Marin, A. H. (2015). Ambiente familiar e desempenho escolar: Uma revisão sistemática. Psicologia da Educação, (40), 41-57. http://pepsic.bvsalud.org/scielo. php?script $=$ sci_arttext\&pid=S1414-69752015000100004\&ln $\mathrm{g}=$ pt\&tlng=pt.

Manso, D. S. S., \& Matos, M. G. (2006). Depressão, ansiedade e consumo de substâncias em adolescentes. Revista Brasileira de Terapias Cognitivas, 2(1), 73-84. https://doi.org/10.5935/18085687.20060008

Marques, C. P., Gasparotto, G. S., \& Coelho, R. W. (2015). Fatores relacionados ao nível de estresse em adolescentes estudantes: Uma revisão sistemática. Salusvita, 34(1), 99-108. https:// secure.unisagrado.edu.br/static/biblioteca/salusvita/salusvita v34_n1_2015_art_07.pdf

Martinelli, $\bar{S}$. C., \& Genari, C. H. M. (2009). Relações entre desempenho escolar e orientações motivacionais. Estudos de Psicologia (Natal), 14(1), 13-21. https://doi.org/10.1590/ S1413-294X2009000100003.

Menezes-Filho, N. A. (2007). Os determinantes do desempenho escolar do Brasil. In: P. G. Duarte, S. D. Silber, \& J. J. M. Guilhoto (Orgs.), O Brasil do século XXI. (1 $1^{\mathrm{a}}$ ed., pp. 231-256).

Monteiro, F. R., Coutinho, M. P. de L., \& Araújo, L. F. (2007). Sintomatologia depressiva em adolescentes do Ensino Médio: Um estudo das representações sociais. Psicologia: Ciência e Profissão, 27(2), 224-235. https://doi.org/10.1590/S141498932007000200005 
Moreno, J., Escobar, A., Vera, A., Calderón, T., \& Villamizar, L. (2009). Asociación entre depresión y rendimiento académico em un grupo de niños de la localidad de Usaquén. Psychologia: Avances de la Disciplina, 3(1), 131-156. https://www.redalyc. org/pdf/2972/297225173007.pdf

Organization for Economic Cooperation and Development. (2018). Programme for International Student Assessment (PISA) 2015. Results in focus. OECD. https://www.oecd.org/pisa/pisa-2015results-in-focus.pdf

Ortega, F. R. F., Mendonza, J. V., \& Ballestas, L. F. F. (2014). Factores psicológicos en adolescentes escolarizados con bajo rendimiento académico: Depresión y autoestima. Encuentros, 12(2), 35-47. https://www.redalyc.org/articulo. oa? id $=476655660003$

Osti, A., \& Brenelli, R. P. (2012). Análise comparativa das representações de alunos e professores sobre as relações entre ensino e aprendizagem. Educação Temática Digital (ETD), 14(1), 363-385. https://doi.org/10.20396/etd.v14i1.1258

Patias, N. D., Machado, W. D. L., Bandeira, D. R., \& Dell'Aglio, D. D. (2016). Depression Anxiety and Stress Scale (DASS-21)short form: Adaptation and validation for Brazilian adolescents. Psico-USF, 21(3), 459-469. https://doi.org/10.1590/141382712016210302

Pérez, M. V., \& Urquijo, S. (2001). Depressión em adolescentes: Relaciones com el desempeño académico. Psicologia Escolar e Educacional, 5(1), 49-58. https://doi.org/10.1590/s141385572001000100006

Pozzobon, M., Falcke, D., \& Marin, A. H. (2018). Intervenção com famílias de alunos com baixo desempenho escolar. Ciências Psicológicas, 12(1), 87-96. https://doi.org/10.22235/ cp.v12i1.1599

Rodrigues, D. G., \& Pelisoli, C. (2008). Ansiedade em vestibulandos: Um estudo exploratório. Revista de Psiquiatria Clínica (São Paulo), 35(5), 171-177. https://doi.org/10.1590/S010160832008000500001

Rotta, N. T., Ohlweiler, L., \& Riesgo, R. S. (2016). Transtornos da aprendizagem: Abordagem neurobiológica e multidisciplinar ( $2^{\mathrm{a}}$ ed.). Artmed.

Salle, E., Rocha, N. S., Rocha, T. S., Nunes, C., \& Chaves, M. L. F. (2012). Escalas psicométricas como instrumentos de rastreamento para depressão em estudantes do Ensino Médio. Revista de Psiquiatria Clínica (São Paulo), 39(1), 24-27. https://doi.org/10.1590/S0101-60832012000100005

San Martín, N. L., Saura, C. I., Cornejo, C. O., Gonzálvez-Maciá, C., Vicent-Juán, M., \& Garcia-Fernandez, J. (2016). Relación entre atribuciones de éxito y fracaso académico y ansiedad escolar em estudiantes chilenos de educación secundaria. Psicología desde el Caribe, 33(2), 146-157. https://doi.org/10.14482/ psdc.33.2.7296
Schermann, L. B., Béria, J. U., Jacob, M. H. V., Arossi, G., Benchaya, M. C., Bisch, N. K., \& Rieth, S. (2014). Estresse em adolescentes: Estudo com escolares de uma cidade do sul do Brasil. Aletheia, 43(44), 160-173. http://pepsic.bvsalud.org/ scielo.php?script $=$ sci arttext\&pid=S1413-03942014000100012

Senna, S. R. C. M. \& Dessen, M. A. (2012). Contribuições das teorias do desevolvimento humano para a concepção contemporânea da adolescência. Psicologia: Teoria e Pesquisa, 28(1), 101-108. https://doi.org/10.1590/S0102-37722012000100013

Soares, A. B., \& Martins, J. S. R. (2010). Ansiedade dos estudantes diante da expectativa do exame vestibular. Paidéia (Ribeirão Preto), 20(45), 57-62. https://doi.org/10.1590/S0103$863 \times 2010000100008$

Silva, P. B. C., Rezende, N. C., Quaresma, T. C. C., \& Chrispino, A. (2016). Sobre o sucesso e o fracasso no Ensino Médio em 15 anos (1999 e 2014). Ensaio: Avaliação e Políticas Públicas em Educação, 24(91), 445-476. https://doi.org/10.1590/S010440362016000200009

De Souza, A. C. M., Siqueira, A. C., Kujawa, I., \& Patias, N. D. (2019). Motivação para aprender em adolescentes do Ensino Médio de uma escola pública militar. Psico, 50(1), e25895. https://doi.org/10.15448/1980-8623.2019.1.25895

Strey, L. M., Souza, M. E. H., \& Carvalho, M. A. (2017). Escola período integral: Sua contribuição para a melhoria da educação. Revista Maiêtica, 5(1), 27-32. https://core.ac.uk/download/ pdf/228915564.pdf

Sy, S. R., Gottfried, A. W., \& Gottfried, A. E. (2013). A transactional model of parental involvement and children's achievement from early childhood through adolescence. Parenting: Science and Practice, 13(2), 133-152. https://doi.org/10.1080/152951 92.2012.709155

Taño, B. L., \& Matsukura, T. S. (2019). Intersetorialidade e cuidado em saúde mental: Experiências dos CAPSi da Região Sudeste do Brasil. Physis: Revista de Saúde Coletiva, 29(1), 1-27. https://doi.org/10.1590/S0103-73312019290108

Thapar A., Collishaw, S., Pine, D. S., \& Thapar, A. K. (2012). Depression in adolescence. Lancet, 379(9820), 1056-67. https://doi.org/10.1016/S0140-6736(11)60871-4

Van Oort, F. V. A., Greaves-Lord, K., Verhulst, F. C., Ormel, J., \& Huizink, A. C. (2009). The developmental course of anxiety symptoms during adolescence: The TRAILS study. Journal of Child Psychology and Psychiatry, 50(10), 1209-1217. https:// doi.org/10.1111/j.1469-7610.2009.02092.x

Wang, Q., Chan, H. W., \& Lin, L. (2012). Antecedents of chinese parents' autonomy support and psychological control: The interplay between parents' self-evelopment socialization goals and adolescents' school performance. Journal of Youth \& Adolescence, 41, 1442-1454. https://doi.org/10.1007/s10964012-9760-0 